\title{
Expression of haloacid dehalogenase gene and its molecular protein characterization from Klebsiella pneumoniae ITB1
}

\author{
Ridani Rino Anggoro ${ }^{1}$ and Enny Ratnaningsih ${ }^{1, *}$ \\ ${ }^{1}$ Biochemistry Research Division, Department of Chemistry, Institut Teknologi Bandung, Jalan Ganesha 10, Bandung 40132, West Java, \\ Indonesia \\ *Corresponding author: enny@chem.itb.ac.id
}

\begin{abstract}
Organohalogen compounds are widely used industrially and agriculturally, as well as in households as flame retardants and refrigerants. However, these compounds can become significant pollutants through their accidental or deliberate release into the environment in large quantities. Dehalogenase is an enzyme with the potential to be used in the removal of organohalogen contaminants. A previous study successfully subcloned a $690 \mathrm{bp}$ of haloacid dehalogenase gene (hakp1) from Klebsiella pneumoniae ITB1 into a pET-30a(+) expression system to achieve high enzyme productivity. IPTG was used as an inducer to express a pET-hakp1 recombinant clone in Escherichia coli BL21 (DE3). The molecular mass of the haloacid dehalogenase Hakp1 protein was $30 \mathrm{kDa}$ as determined by SDS-PAGE. Zymogram analysis showed that this recombinant protein has dehalogenase activity as shown by the formation of $\mathrm{AgCl}$ white precipitate. A quantitative assay of haloacid dehalogenase Hakp1 gave a specific activity of $84.29 \mathrm{U} / \mathrm{mg}$ with the optimum temperature of $40^{\circ} \mathrm{C}$ at $\mathrm{pH}$ 9. Predicted threedimensional structure of Hakp1 showed $\alpha / \beta$ motif folding which comprised of cap and core domain. The predicted active sites of Hakp1 were Asp8, Glu10, Leu22, Phe23, Trp90, Ser125, Ser126, Lys159, and Asp184 with Asp8, Glu10, Ser126, and Lys159 act as binding residue. This recombinant haloacid dehalogenase clone provides an alternative agent for effective bioremediation of organohalogen pollutants.
\end{abstract}

KEYWORDS haloacid dehalogenase; Klebsiella pneumoniae ITB1; organohalogen

\section{Introduction}

Organohalogen compounds are compounds that contain carbon-halogen bond. Large-scale synthesis and extensive uses of these organic chemicals in many areas of agriculture and industry have led to widespread distribution of harmful compounds in the environment and created pollution problems. These chemicals, which are produced industrially and introduced into the environment as novel compounds, or at a concentration that exceeds the normal amount, are called xenobiotics (Top and Springael 2003). Organohalogen compounds, which constitute of more than 75\% compounds listed as "priority pollutants", have been widely used as herbicides, pesticides, fungicides, solvents, plasticizers, paints, printing ink, adhesives, hydraulic and heat transfer fluids, flame retardants, refrigerants, additives for cutting oils, textile auxiliaries, and intermediates for other fine chemical synthesis (Fetzner and Lingens 1994; Janssen et al. 1994).

These chemically synthesized organic compounds are not readily degraded in the environment, and many are accumulate in soil water, groundwater, lake, and river (Esteve-Núñez et al. 2001; Pervova et al. 2002). Besides local and regional contamination, organohalogen continues to be a global issue pollutants, partly because its transport through water and air helps these compounds to spread across the Earth (Iwata et al. 1993). The persistence of these compounds in the environment causes considerable human health problems because of their toxicity and bioaccumulation in the food chain and ground water (Brokamp et al. 1997; Dórea 2008). It is well-known that some organohalogen compounds degrade slowly and form toxic intermediates which may affect cellular metabolic processes (Slater et al. 1995; Janssen et al. 2001).

Reactions between natural organic matter and chlorine compounds produce haloacetic acids at ppt to ppb ranges in drinking water distribution systems and in ppb to ppm ranges in wastewater (Rebhun et al. 1997). The concern over the carcinogenicity of haloacetic acids led the United States Environmental Protection Agency to regulate the allowable concentration of haloacetic acids in drinking water as part of the Disinfectants and Disinfection by Products Rule promulgated in 1998. Five haloacetic acids, known as HAA, are regulated as a part of the rule. These are monochloroacetic acid (MCA), dichloroacetic acid (DCA), trichloroacetic acid (TCA), 
bromoacetic acid (BAA), and dibromoacetic acid (DBA). HAA, which is expressed as the sum of the concentrations of these acids, is currently limited there to $60 \mathrm{ppb}$ (Xie and Zhou 2002). The current concentration of HAA in the Sidoarjo (Rosyidi 2010) and Sukabumi (Indraningsih et al. 2006) water supply sampled was approximately 50 ppb. Because of their widespread occurrence, toxicity to plants and aquatic organisms, and most importantly their suspected human carcinogenicity, there is a great need to find treatment methods for haloacetic acids.

In nature, some microorganisms are known as able to degrade organohalogen compounds and play a major role in biodegradation and decontamination (Weightman and Slater 1980; de Lorenzo 2008). Microbes degrade organohalogen compounds in order either to exploit them for growth as a carbon source and/or as a means of protection against its toxicity (Müller and Lingens 1986). There are several key requirements for a microorganism to degrade xenobiotics: (a) the ability to transport the compound into the cell where enzyme action can occur; (b) degradative catabolic genes must be expressed producing functional enzymes; (c) and the product of enzyme must be able to enter metabolism pathways (i.e. to be a growth substrate) (Weightman and Slater 1980; Weightman et al. 1985). Dehalogenases are key enzymes in the degradation of organohalogen compounds (Fetzner and Lingens 1994; Janssen et al. 1994).

A problem in using a wild-type bacterial dehalogenase for industrial biotransformation is rare because of their basal level availability and its low efficiency in degrading organohalogen pollutants. The advance of molecular biotechnology provides a solution to increase dehalogenases production by microbes through cloning and subcloning of the gene encoding dehalogenase into expression system for high enzyme productivity. Previous studies had been successfully cloned the haloacid dehalogenase gene from Klebsiella pneumoniae ITB1 (hakp1) into pET-30a(+) expression vector, named as pET-hakp1 (Anggoro and Ratnaningsih 2017). This system would make good expression because it contains a strong regulatable promoter for gene expression. In order to analyze the function of hakp1 gene, the pET-hakp1 should be transformed into Escherichia coli BL21 (DE3) and expressed by IPTG induction, which is performed in this research.

\section{Materials and methods}

\subsection{Bacterial strains and chemicals}

All bacterial strains were obtained from the Biochemistry Laboratory of ITB. E. coli BL21 (DE3) was used as bacterial hosts. Monochloroacetic acid (MCA), mercury(II)thiocyanate $\left(\mathrm{Hg}(\mathrm{SCN})_{2}\right)$, iron(II)ammonium sulfate $\left(\mathrm{Fe}\left(\mathrm{NH}_{4}\right)_{2}\left(\mathrm{SO}_{4}\right)_{2}\right)$ were obtained from Merck. Isopropyl-B-D-Thiogalactopyranoside (IPTG) from Amresco was used as inducer for expression. Kanamycin from Bioline were used as antibiotic to screen positive re- combinant clones. Natrium chloride, yeast extract, and tryptone from Liochemfil were used as ingredients in Luria-Bertani (LB) medium.

\subsection{Transformation and clone selection}

The pET-hakp1 recombinant clone isolated from $E$. coli TOP10 was transformed into competent E. coli BL21(DE3) cells using heat shock method (Sambrook and Russell 2001). The obtained transformants were plated on LB medium supplemented with $50 \mu \mathrm{g}$ kanamycin for antibiotic screening. The E. coli BL21 (DE3) colonies harboring pET-hakp1 recombinant clone would survived on this medium due to the presence of kanamycin resistance gene in pET-30a(+).

\subsection{Expression and extraction of haloacid dehaloge- nase}

Single colony of E. coli BL21(DE3) harboring pET-hakp1 was grown at $37^{\circ} \mathrm{C}$ on $100 \mathrm{~mL}$ liquid LB medium supplemented with $50 \mu \mathrm{g}$ kanamycin. Induction was performed by adding $1 \mathrm{mM}$ IPTG when the $450 \mathrm{~nm}$ optical density of this culture reached around 0.6. These induced cells were then harvested by centrifugation at 5,000 rpm for $10 \mathrm{~min}$ after 4-h induction, washed and resuspended in $10 \mathrm{~mL}$ of $50 \mathrm{mM}$ Tris-acetate buffer ( $\mathrm{pH}$ 7.5). Cells were disrupted by sonication for $30 \mathrm{~min}$ at $4^{\circ} \mathrm{C}$. A crude extract was obtained after the cell debris had been removed by centrifugation.

\subsection{Estimation of haloacid dehalogenase molecular mass}

The molecular mass of denatured protein from the crude extract was estimated by sodium dodecyl sulfatepolyacrylamide gel electrophoresis (SDS-PAGE) utilizing protein ladder standard. Gel was visualized using staining Commassie Brilliant Blue solution.

\subsection{Zymogram assay}

Qualitative assay of haloacid dehalogenase activity in the crude extract was determined by zymogram. Crude extracts were electrophorized using Native-PAGE, and the resulted gel was incubated with $50 \mathrm{mM}$ monochloroacetic acid (MCA) at $40^{\circ} \mathrm{C}$ for $10 \mathrm{~min}$, and then soaked and incubated at room temperature for $1 \mathrm{~h}$ in $0.1 \mathrm{M} \mathrm{AgNO}_{3}$ solution. Haloacid dehalogenase activity was showed by the formation of $\mathrm{AgCl}$ white precipitate.

\subsection{Enzymatic assay}

Haloacid dehalogenase activities were routinely measured with MCA as substrate. A suitable enzyme solution was incubated in $1 \mathrm{~mL}$ of $5 \mathrm{mM}$ MCA with various $\mathrm{pH}$ and temperature for $10 \mathrm{~min}$. Liberation of chloride ion was followed spectrophotometrically as described by Bergmann and Sanik (1957). One unit of dehalogenase activity was defined as the amount of enzyme that catalyzed the forma- 


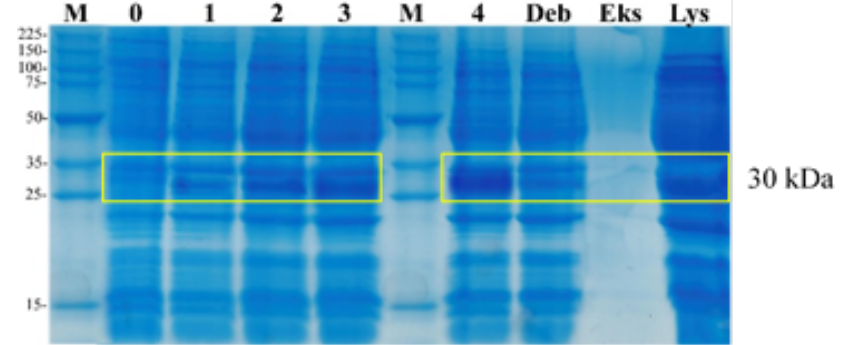

(a)

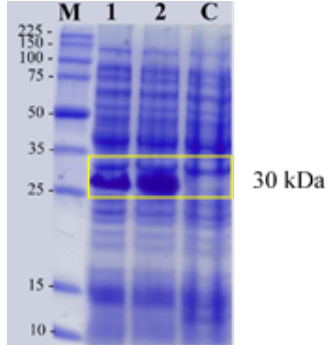

(b)

FIGURE 1 SDS-PAGE electropherogram of the pET-hakp1 gene expression in E. coli BL21(DE3). (a) Overexpression analysis; M: Promega Broad Range Protein Ladder; 0: Total cell protein before IPTG induction; 1-4: Total cell protein after IPTG induction from 1 to 4 h; Deb: Total protein in cell debris; Eks: Protein content in the medium (representing extracellular protein); Lis: Total protein in the cell lysate. (b) Molecular mass analysis of Hakp1. M: Promega Broad Range Protein Ladder; 1-2: Cell lysate protein from recombinant E. coli BL21 (DE3); $\mathrm{C}$ : Cell lysate protein from non-recombinant E. coli BL21 (DE3).

tion of $1 \mu \mathrm{mol}$ of chloride ion per min. Protein was determined using Bradford reagent with bovine serum albumin as standard (Bradford 1976).

\subsection{Bioinformatic analysis}

The three-dimensional structure of deduced Hakp1 protein was predicted using Swiss Model and I-TASSER program. The active site of this protein was analyzed using Sequences Annotated by Structure (SAS). Molecular docking was done using Autodock Vina to determine the binding site, ligand conformation, and affinity energy.

\section{Results and discussion}

\subsection{Expression of recombinant hakp1 gene on E. coli BL21(DE3) biofilm qualitative analysis by SEM}

Expression of hakp1 gene in pET-hakp1 recombinant clone was studied by induction of IPTG. The SDS-PAGE analysis on the cell pellet protein showed that the overexpression was occurred after 4-h induction (Figure 1a). On this gel, haloacid dehalogenase was seen more concentrated in the cell lysate compare to that in the cell debris. This fact indicated that the haloacid dehalogenase was present as soluble protein. Molecular mass estimation of this haloacid dehalogenase recombinant was obtained at around $30 \mathrm{kDa}$ (Figure 1b). This size was larger than 25.5 $\mathrm{kDa}$ in silico analysis of Hakp1 protein, which was possibility due to the addition of fusion 6x His-Tag, S-Tag, and enterokinase site on its $\mathrm{N}$-terminus.

\subsection{Dehalogenase activity of recombinant haloacid dehalogenase}

The zymogram assay showed that the haloacid dehalogenase produced by pET-hakp1 has detectable activity on MCA. This result was proved by the formation of $\mathrm{AgCl}$ white precipitate observable on the gel (Figure 2). The size of this active halaocid dehalogenase was approximately 30 $\mathrm{kDa}$.

Further assay of recombinant haloacid dehalogenase activity were determined by identified chloride ion re-

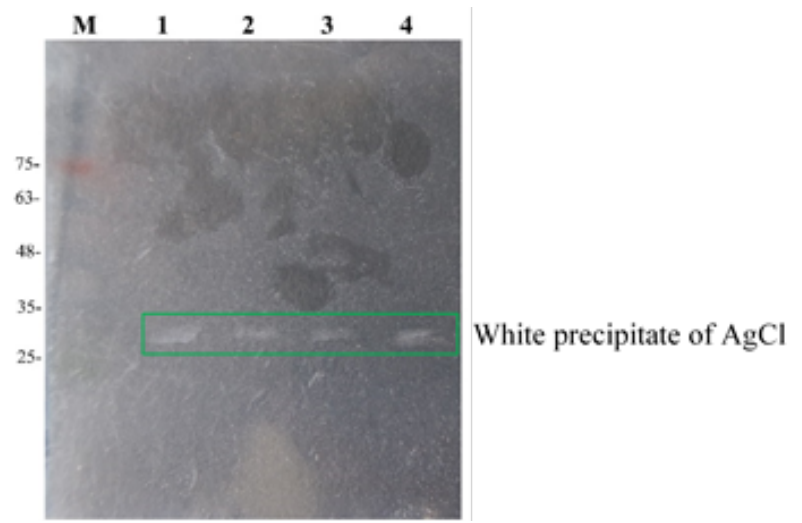

FIGURE 2 Zymogram assay of recombinant haloacid dehalogenase; M: $1^{\text {st }}$ Base prestained protein ladder; 1-4: Cell lysate protein.

leased upon incubation with $5 \mathrm{mM}$ MCA, by varying $\mathrm{pH}$ (Figure 3a) and temperature (Figure $3 b$ ) to obtain optimum condition of enzymatic reaction. The result suggests that the maximum activity of the recombinant haloacid dehalogenase was $84.29 \mathrm{U} / \mathrm{mg}$ at $40^{\circ} \mathrm{C}$ and $\mathrm{pH}$ 9. At this condition, the total chloride ion detected was $684 \mu \mathrm{M}$ representing $13.68 \%$ of MCA degradation. This activity was three times higher compare to haloacid dehalogenase activity from the wild-type K. pneumoniae ITB1 (Tahya and Ratnaningsih 2015). The specific activity was not as high as expected because the haloacid dehalogenase crude used was still impure.

\subsection{Bioinformatics of protein Hakp1}

The predicted three-dimensional structure of Hakp1 was done by Swiss-Model and I-TASSER programs (Figure $4 a)$. The result indicated that Hakp1 showed $\alpha / \beta$ folding motif. This model consists of five $\beta$-sheet surrounded by $\alpha$-helix, which is in a good agreement with haloacid dehalogenase (de Jong and Dijkstra 2003). As expected, the haloacid dehalogenase from K. pneumoniae ITB1 also has a core domain resembles Rossmann-fold-like structure where five parallel of $\beta$-sheets are flanked by five $\alpha$-helixes. The predicted active site of Hakp1 from $K$. 


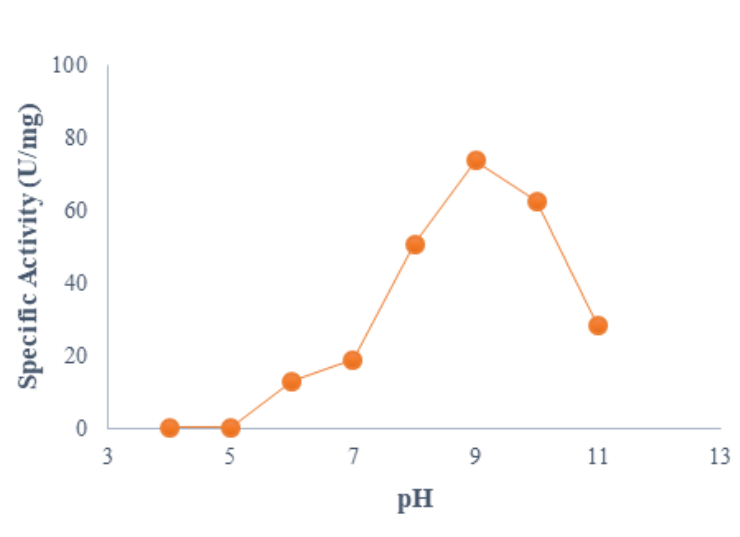

(a)

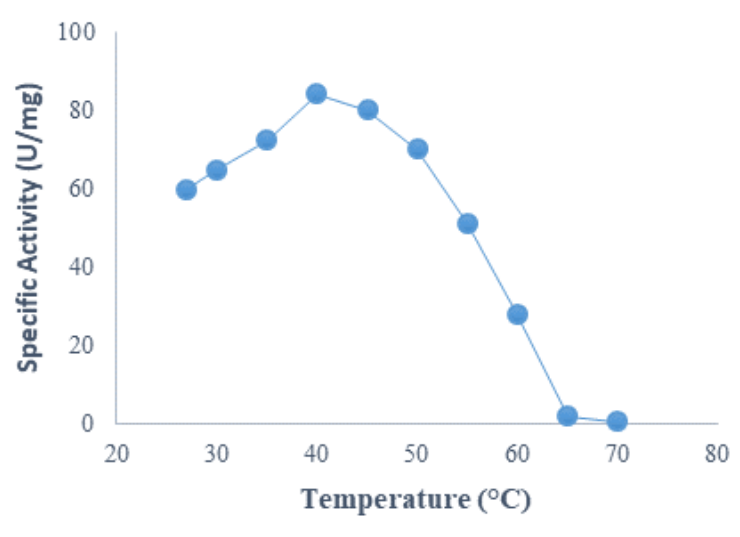

(b)

FIGURE 3 Activity assay of recombinant haloacid dehalogenase (a) Effect of pH on enzyme activity. (b) Effect of temperature on enzyme activity

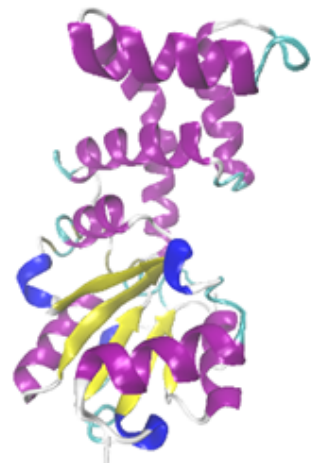

(a)

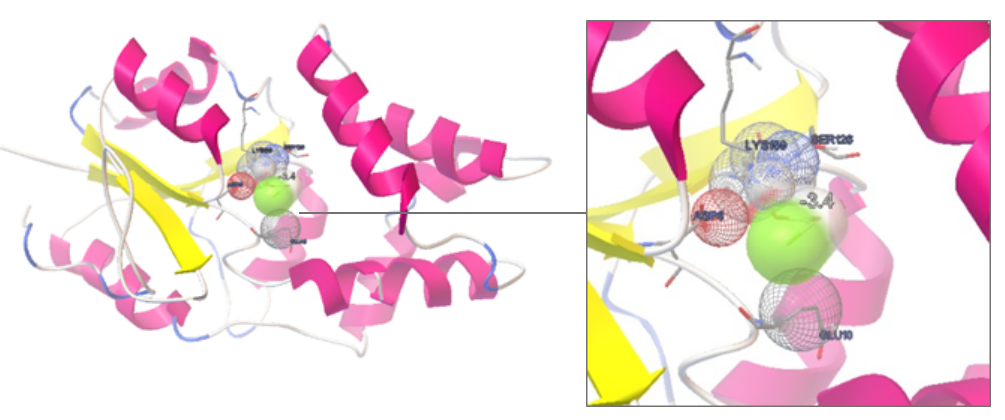

(b)

FIGURE 4 Bioinformatics analysis of Hakp1. Predicted three-dimensional structure (a) and molecular docking (b) of Hakp1 protein with MCA ligand.

pneumoniae ITB1 has Asp8, Glu10, Leu22, Phe23, Trp90, Ser125, Ser126, Lys159, and Asp184 residues, which are similar to Asp9, Ser154, Lys159, and Asp188 of haloacid dehalogenase superfamilies Enolase-phospatase E1 protein from Homo sapiens (Wang et al. 2005). Molecular docking result suggested that Asp8, Glu10, Ser126, and Lys159 are the binding residues in Hakp1 (Figure 4b). The identified lowest affinity energy of Hakp1 was -3.4 $\mathrm{kcal} / \mathrm{mol}$.

\section{Conclusions}

The pET-hakp1 system have been successfully express a $30 \mathrm{kDa}$ recombinant haloacid dehalogenase. This recombinant dehalogenase has $84.29 \mathrm{U} / \mathrm{mg}$ optimum activity at $40^{\circ} \mathrm{C}$ and $\mathrm{pH}$ 9. Dehalogenase activity assay showed that the enzymes can degrade $13.68 \%$ chloride ion from $5 \mathrm{mM}$ monochloroacetic acid substrate. Predicted threedimensional Hakp1 structure showed $\alpha / \beta$ folding motif with Asp8, Glu10, Ser126, and Lys159 as binding residues. These result suggested that the recombinant haloacid dehalogenase clone has potentially used as bioremediation agent for organohalogen pollutants in the environment. Further studies with enzyme purification and gene mutation needed to be done to improve the purity and activity of the recombinant haloacid dehalogenase.

\section{Acknowledgments}

We would like to acknowledge Lembaga Pengelola Dana Pendidikan (LPDP) Indonesia for full financial support on this research.

\section{Authors' contributions}

ER, RRA designed the study. RRA carried out the laboratory work. ER, RRA analyzed the data. ER, RRA wrote the manuscript. All authors read and approved the final version of manuscript.

\section{Competing interests}

The authors declare no competing interest. 


\section{References}

Anggoro RR, Ratnaningsih E. 2017. Subcloning of haloacid dehalogenase gene from Klebsiella pneumoniae strain ITB1 into pET-30a expression vector. volume 3 of Proceedings of the 7th Annual Basic Science International Conference. Malang: Brawijaya University. p. 99-104.

Bergmann JG, Sanik J. 1957. Determination of trace amounts of chlorine in naphtha. Anal Chem. 29(2):241-243. doi:10.1021/ac60122a018.

Bradford MM. 1976. A rapid and sensitive method for the quantitation of microgram quantities of protein utilizing the principle of protein-dye binding. Anal Biochem. 72(1):248-254. doi:10.1016/00032697(76)90527-3.

Brokamp A, Schwarze R, Schmidt FRJ. 1997. Homologous plasmids from soil bacteria encoding d,lhalidohydrolases. Curr Microbiol. 34(2):97-102. doi:10.1007/s002849900151.

de Jong RM, Dijkstra BW. 2003. Structure and mechanism of bacterial dehalogenases: different ways to cleave a carbon-halogen bond. Curr Opin Struct Biol. 13(6):722-730. doi:10.1016/j.sbi.2003.10.009.

de Lorenzo V. 2008. Systems biology approaches to bioremediation. Curr Opin Biotechnol. 19(6):579589. doi:10.1016/j.copbio.2008.10.004.

Dórea JG. 2008. Persistent, bioaccumulative and toxic substances in fish: human health considerations. Sci Total Environ. 400(1-3):93-114. doi:10.1016/j.scitotenv.2008.06.017.

Esteve-Núñez A, Caballero A, Ramos JL. 2001. Biological degradation of 2,4,6-trinitrotoluene. Microbiol Mol Biol Rev. 65(3):335-352. doi:10.1128/MMBR.65.3.335-352.2001.

Fetzner S, Lingens F. 1994. Bacterial dehalogenases: biochemistry, genetics, and biotechnological applications. Microbiol Rev. 58(4):641-685.

Indraningsih, Bahri S, Sani Y. 2006. Beberapa faktor yang mempengaruhi keamanan pangan asal ternak di Indonesia. Wartazoa 16:1-13.

Iwata H, Tanabe S, Sakai N, Tatsukawa R. 1993. Distribution of persistent organochlorines in the oceanic air and surface seawater and the role of ocean on their global transport and fate. Environ Sci Technol. 27(6):1080-1098. doi:10.1021/es00043a007.

Janssen DB, Oppentocht JE, Poelarends GJ. 2001. Microbial dehalogenation. Curr Opin Biotechnol. 12(3):254-258. doi:10.1016/s0958-1669(00)002081.

Janssen DB, Pries F, Van der Ploeg JR. 1994. Genetics and biochemistry of dehalogenating enzymes. Annu Rev Microbiol. 48(1):163-191. doi:10.1146/annurev.mi.48.100194.001115.

Müller R, Lingens F. 1986. Microbial degradation of halogenated hydrocarbons: A biological solution to pollu- tion problems? Angew Chem Int Ed Engl. 25(9):779789. doi:10.1002/anie.198607791.

Pervova MG, Kirichenko VE, Pashkevich KI. 2002. Determination of chloroacetic acids in drinking water by reaction gas chromatography. J Anal Chem. 57(4):326330. doi:10.1023/A:1014902431520.

Rebhun M, Heller-Grossman L, Manka J. 1997. Formation of disinfection byproducts during chlorination of secondary effluent and renovated water. Water Environ Res. 69(6):1154-1162. doi:10.2175/106143097x125902.

Rosyidi M. 2010. An effect of a breakpoint chlorination BPC coliform total number from hospital wastewater in Sidoarjo. Undergraduate thesis. [Surabaya]: Institut Teknologi Sepuluh Nopember.

Sambrook J, Russell DW. 2001. Molecular cloning: a laboratory manual. Cold Spring Harbor, NY: CSHL Press.

Slater JH, Bull AT, Hardman DJ. 1995. Microbial dehalogenation. Biodegradation 6(3):181-189. doi:10.1007/BF00700456.

Tahya CY, Ratnaningsih E. 2015. Cloning and sequencing of haloacid dehalogenase gene from Klebsiella pneumoniae ITB1. Procedia Chem. 16(Supplement C):121-128. doi:10.1016/j.proche.2015.12.039.

Top EM, Springael D. 2003. The role of mobile genetic elements in bacterial adaptation to xenobiotic organic compounds. Curr Opin Biotechnol. 14(3):262-269. doi:10.1016/s0958-1669(03)00066-1.

Wang H, Pang H, Bartlam M, Rao Z. 2005. Crystal structure of human E1 enzyme and its complex with a substrate analog reveals the mechanism of its phosphatase/enolase activity. J Mol Biol. 348(4):917-926. doi:10.1016/j.jmb.2005.01.072.

Weightman AJ, Slater JH. 1980. Selection of Pseudomonas putida strains with elevated dehalogenase activities by continuous culture growth on chlorinated alkanoic acids. Microbiology 121(1):187-193. doi:10.1099/00221287-121-1-187.

Weightman AJ, Weightman AL, Slater JH. 1985. Toxic effects of chlorinated and brominated alkanoic acids on Pseudomonas putida PP3: selection at high frequencies of mutations in genes encoding dehalogenases. Appl Environ Microbiol. 49(6):1494-1501.

Xie YF, Zhou HJ. 2002. Use of BAC for HAA removal Part 2, Column Study. J Am Water Works Assoc. 94(5):126-134. 